\title{
Experimental study of concrete mixtures to produce UHPRC using sustainable brazilians materials
}

\section{Estudio experimental de mezclas de concreto para producir UHPRC usando materiales brasileños sustentables}
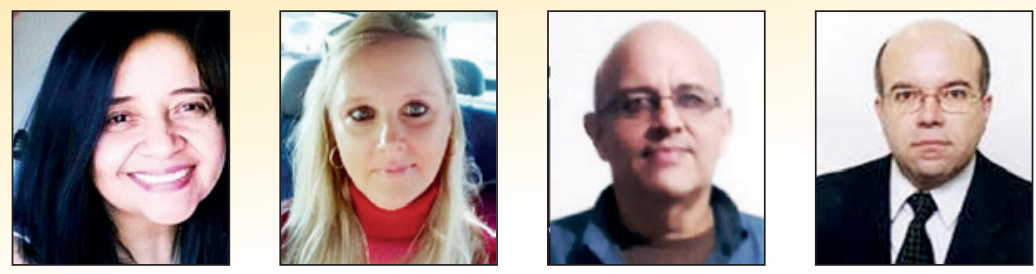

R. R. AGUERO rosangel.rojas@ufrgs.br https://orcid.org/0000-0003-0776-599X

C. KORZENOWSKI christa-korzenowski@uergs.edu.br https://orcid.org/0000-0001-6500-2910

J. R. Y. AGUIRRE a jose.aguirre@ufrgs.br
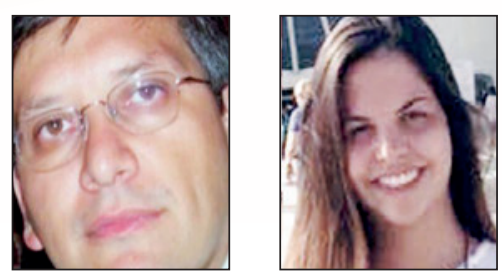

\section{A. CAMPOS FILHO americo@ufrgs.br https://orcid.org/0000-0001-7764-3010 \\ L. C. P. DA SILVA FILHO Icarlos66@gmail.com https://orcid.org/0000-0003-3703-7328}

C. S. MALLMANN carolinamallmann98@gmail.com https://orcid.org/0000-0003-4856-5361

\section{Abstract}

An experimental study is presented to produce Ultra High Performance Reinforced Concrete (UHPRC) with sustainable materials produced in Brazil. A complete factorial arrangement was defined and five controllable factors were selected based on the literature review. Cylindrical specimens were tested at 7,14 and 28 days of curing, with and without heat treatment. The residual deviations of the results were determined and an analysis of variance using ANOVA was applied to know the contribution of each controllable factor on the compressive strength, which reached a maximum value of $138.12 \mathrm{MPa}$. Finally, a mix design is proposed to obtain UHPRC by applying a simple manufacturing procedure using commercial materials, with which a high performance concrete can be obtained, reaching at least $70 \%$ of its strength in seven days.

Keywords: UHPRC, sustainable, compressive strength, ANOVA.

\section{Resumen}

Se presenta un estudio experimental para producir Ultra High Performance Reinforced Concrete (UHPRC) con materiales sustentables producidos en Brasil. Un arreglo factorial completo fue definido y cinco factores controlables fueron seleccionados basados en la revisión bibliográfica. Especímenes cilíndricos fueron ensayados a los 7, 14 y 28 días de curado, con y sin tratamiento térmico, para determinar la resistencia a la compresión. Desvíos residuales fueron determinados y se aplicó un análisis de varianza usando ANOVA para conocer la contribución de cada factor controlable sobre la resistencia a la compresión, la cual alcanzó un valor máximo de 138,12 MPa. Al final se propone un diseño de mezcla para obtener UHPRC aplicando una metodología simple de fabricación usando materiales comerciales, con los cuales se puede obtener un concreto de alto desempeño que alcanza a los siete días de curado el $70 \%$ de su resistencia.

Palavras-chave: UHPRC, sustentable, resistencia a la compresión, ANOVA. 


\section{Introduction}

Ultra High Performance Fiber Reinforced Concrete (UHPFRC) is an innovative material that it can achieve resistances to the upper compression to the $150 \mathrm{MPa}$ with 28 days of curing. This allows the construction of structural elements that bear large spans with a smaller cross section than those built with traditional concrete. Its composition includes cement, mineral additives (eg silica fume, fly ash, granular blast furnace slag, quartz powder), silica sand, superplasticizer and water, to form a dense matrix without coarse aggregate with low porosity and high strength.

This high resistance is achieved mainly by the large amount of cement in the mixture, making it also expensive in a material that impacts the environment. The cost of UHPFRC per $\mathrm{m}^{3}$ has been reported four to five times higher than traditional concrete, using only cement as binder, Fehling, et al. [1], however, using UHPFRC can reduce by one third or half the weight of the structure under the same loads, Yoo and Yoon [2], allowing to design foundations with smaller geometries and in general it makes possible that the final cost of the work may be diminished, Tanaka, et al. [3].

At first glance it may be thought that concrete with ultra-high performance will require high amounts of cement and consequently will cause great polluting effects for the environment. It is well known that the construction industry emits a third of the $\mathrm{CO}_{2}$ to the atmosphere where the cement is responsible for $7 \%$, UNSTAT [4]. However, sustainable designs can be produced with UHPFRC by adding Silica Fume (SF) and blast furnace slag or Ground Granulated Blast-furnace Slag (GGBS) as partial substituting binder materials of cement. The SF and the GGBS are materials from industrial waste that provide, in addition to savings, lower $\mathrm{CO}_{2}$ emissions to the environment for each $\mathrm{m} 3$ of ultra-resistant concrete manufactured. Several researches have been developed using UHPFRC with green design and it has been demonstrated that the use of sustainable materials, partial cement substituents, do not significantly decrease the compressive strength of the UHPFRC, besides making it economically feasible. The research of Hassan et al. [5], Yu et al [6], Habel et al [7] and Yang et al. [8], are an example of this, in all those cases industrial residues (SF, GGBS) were considered as substitute materials for cement, with which economic mixtures with ultrahigh strength were obtained.

Mixtures of UHPFRC can be manufactured without the inclusion of fibers, called UHPRC, in these cases the compressive strength after 28 days of curing can vary between 100 and $130 \mathrm{MPa}$. In this work, we intend to study nine types of mixtures to produce UHPRC using sustainable materials from Brazil. An analysis of variance applying ANOVA will be applied to the results to determine the percentage of contribution of each controllable factor (age of the sample, granulometry of the slag, type of mixture and type of curing) in the response variable (compressive strength).

\subsection{Objective}

Produce mixing designs for concrete with ultra-high performance without the use of fibers (UHPRC) using sustainable materials from Brazil.

\section{Literature review}

\subsection{Historic development of concrete with ultra-high strength}

After Aspdin and Parker patented Portland Cement in 1824, its use as a cementitious material in concrete increased rapidly. When Joseph Lambot in 1849 built and patented his ship using concrete and steel detonated the visionary spirit of Joseph Monier, who, buying that patent, solved the problem of the fragility of the flowerpots that he was building, and in the following three decades the advance of his technique was such that achieved to build beams and bridges in reinforced concrete. Since then the progress of civil engineering was accelerated around the world, illustrated by the construction of skyscrapers, bridges with large lights, structures for water control, etc. In each of these works, new challenges were assumed for structural mechanics and for knowledge in construction materials, in the present, the challenge of using reinforced concrete in a rational and sustainable manner are added. A continuación se realiza, en orden cronológico, una breve revisión de la literatura con enfoque en la evolución de la resistencia a la compresión del concreto.

Year 1874: Berard, Ahoille obtained a patent called "Improvements of the artificial stone for pavements", in which he describes the process to obtain a block of artificial gray granite stone, filling molds with a mixture formed by two parts of gravel, two parts of sand, two parts of hydraulic lime, a part of iron waste similar to a fiber and water.

Year 1898: René Féret [10] established the principles of optimal composition that lead to obtaining concrete of specified strength. Established the relationship between the compressive strength of concrete and the volumes of cement, water and voids.

Year 1927: Otto Graf, pioneer in the field of concrete roads, established the general criteria that must be met to build roads with high resistance to compression, impact, traction and resistance to chemical attacks, Reinhardt [11]. He also investigated and published the influence of fines on cement properties, the water / cement ratio $(\mathrm{w} / \mathrm{c})$ on the strength and the use of furnace slag to decrease the shrinkage of the concrete. In the 1950s, it reached $70 \mathrm{MPa}$ in concrete mixtures used on roads with high durability, Fehling et al. [1].

Year 1930: Eugene Freyssinet [12], designed and built beams for bridges with high initial strength and included heat treatment in curing. It used steam around concrete molds to significantly shorten the time of concrete curing, aspects that are currently in force to accelerate the development of UHPRC strength.

Year 1966: Kurt Walz showed that, using special production methods, it was possible to achieve a resistance of $140 \mathrm{MPa}$, Fehling et al. [1].

Year 1970: Yudenfreund, et al. [13] reached $240 \mathrm{MPa}$ after 180 days of curing at $25^{\circ} \mathrm{C}$, using Portland cement pastes with w/C ratios of 0.2 and 0.3 . The specimens tested were cubes compressed laterally, to avoid the effects of a possible sedimentation before hardening. They used two types of previously ground Clinker, until reaching a fineness of 6000 to $9000 \mathrm{~cm} 2 / \mathrm{g}$ measured by the Blaine method. 
Year 1972: Roy, et al [14] reached 509.52 MPa using cylinders, 1/2" diameter by $1 / 2$ " high, with Portland cement paste with zero porosity, applying high densification pressure (between 25000 to 50000 psi) with thermal treatment close to $150{ }^{\circ} \mathrm{C}$. Using 100000 psi pressure without thermal treatment they achieved $318 \mathrm{MPa}$.

Year 1973: Roy and Gouda [15] experienced high resistances, between $175.40 \mathrm{MPa}$ and $652.24 \mathrm{MPa}$ applying high temperature and/or pressure, verified that the high compressive strength of concrete is mainly due to the low porosity of the concrete mix, and not only to the largest amount of anhydrous Clinker.

Year 1981: Birchall et al. [16] showed that the removal of macroscopic faults during the preparation of cement pastes, allows to obtain resistance to bending between 60 to $70 \mathrm{MPa}$ and compressive strengths greater than $200 \mathrm{MPa}$, without the need for fiber reinforcement and without the need to apply a high compaction pressure. The removal of these faults was done by combining the control of the rheological properties of the material and an efficient mixture, this new concrete was classified as Macro Defect Free (MDF). Bache, H. [17] presented an article in the 2nd international conference on superplasticizers in concrete, in which he describes a new type of material typified as Densified Systems Particles (DSP), with a high durability, and which has three to five times the strength of the traditional concrete of that time. Such properties are possible to achieve thanks to the use of a large amount of silica fume and superplasticizer, which allows a dense packing of the concrete matrix and can reach resistance between 120 to 270 $\mathrm{MPa}$. They also discuss geometrical, kinematic and dynamic principles to arrange fine particles in a dense structure, as well as in the development of new material properties, such as ductility and high tensile strength.

Year 1982: Lankard and Lease [18] proposed the Slurry Infiltrated Fibered Concrete (SIFCON) technique which involves filling the formwork with bulk fibers and injecting a fluid mortar suspension. They verified that the addition of steel fibers to refractory cements, with a proportion of $2 \%$ in volume, give place to significant improvements in the properties of these materials, and they also proposed a new procedure where steel concentrations are higher than $16 \%$ in volume, the engineering properties and in-service behavior of some of these reinforced composite materials are discussed.

Year 1983: Hjorth et al. [19] patented and marketed a mixture of concrete with small densified particles. They also used silica fume as a mineral additive and as a chemical additive to the superplasticizer, with both reaching compressive strengths between 120 and $250 \mathrm{MPa}$. Year 1994: Larrard and Sedran [20] were one of the first to use the term Ultra-High Performance Concrete (UHPC) to refer to a fluid mortar produced with an optimum density. They used the Suspension Solids Model (SSM), as a particle packing model, based on the Mooney model. They tested different mixtures, with a water/ binders ratio $(\mathrm{w} / \mathrm{b})$ between 0.106 and 0.178 . They reached a resistance of $237,90 \mathrm{MPa}$ when applying curing system that initially includes the submerged specimens for 4 days in water at $90^{\circ} \mathrm{C}$ and later at room temperature.

Year 1995: Richard and Cheyrezy [21] applied a number of basic design principles regarding the composition, mixing and subsequent thermal curing of concrete, to obtain a ductile material with ultra-high strength called Reactive Powder Concrete (RPC). The ductility was obtained by the addition of steel fibers to the mixture.
They undertook a research program to develop concrete with resistances between 200 and $800 \mathrm{MPa}$, through improvements in the homogeneity of the mixture. This was done by removing coarse aggregate, improving compacted density and applying pressure before and during adjustment. They also made improvements in the microstructure by thermal treatment in curing, increased ductility by incorporating small-sized steel fibers, and maintaining the mixing and formwork procedures as close as possible to the existing practice.

Year 2005: Rossi et al. [22] tested cylinders of $11 \mathrm{~cm}$ in diameter and $22 \mathrm{~cm}$ in height to obtain $205 \mathrm{MPa}$ using mixtures with different percentages and types of steel fibers, including heat treatment in curing which consisted of placing the specimens in a drying oven $90^{\circ} \mathrm{C}$ for four days 48 hours after being unmolded. Lim and Nawy [23] reached $121 \mathrm{MPa}$ in $100 \mathrm{~mm}$ concrete cubes with $1.5 \%$ fibers stored in a humid chamber without heat treatment during curing. Year 2006: Habel et al. [7] obtained $168 \mathrm{MPa}$ at 28 days, used cement with low $\mathrm{C} 3 \mathrm{~A}$ content and short steel fibers in the mixture, with a w/b ratio of 0.14 and $w / c$ of 0.18 . They were demolded on the third day and the test bodies were cured in water at $20{ }^{\circ} \mathrm{C}$.

Year 2007: Graybeal, B. [24] reached $193 \mathrm{MPa}$ at 28 days for the specimens with heat treatment in the curing, in those cases observed a stabilization of the value of the resistance at 48 hours of curing. He also tested specimens without heat treatment, reaching $126 \mathrm{MPa}$, in those cases he observed that significant gains in resistance continued after eight weeks of emptying.

Year 2008: Thanh, L. [25] developed an extensive experimental work studying the influence of the ratio $w / c, w / b$, heat treatment in curing, influence of GGBS, SF and pulverized ash, fiber content and effect of the size, and type of aggregate in the mix design. It reached compression resistance in ranges between 185.90 and 182.20 MPa, applying heat treatment and placing $2.5 \%$ of short steel fibers. It also reached 143.90 and $129.40 \mathrm{MPa}$ without heat treatment, in cubes of $50 \mathrm{~mm}$ and $100 \mathrm{~mm}$ respectively.

Year 2009: Yang et al. [8] focused their research on the reduction of production costs and on-site use (in situ) of the mixture. They used two different types of aggregates to replace the silica sand, first they incorporated broken glass recycled from glass production or Recycled Glass Cullet (RGC) and secondly they used two types of local sands. They applied thermal treatment in the curing process, they tested compressed concrete cubes of $50 \mathrm{~mm}$. They showed that using the glass the resistance decreased by $20 \%$ and using the local sands no significant difference in the resistance compared to the use of silica sand was obtained. They reached resistances between 160 and $180 \mathrm{MPa}$ using local sands, cured at $90^{\circ} \mathrm{C}$. They also reached resistances between 100 and $140 \mathrm{MPa}$, cured at 20 ${ }^{\circ} \mathrm{C}$. Using RGC they reached between 150 and $160 \mathrm{MPa}$ at $90{ }^{\circ} \mathrm{C}$ and between 80 and $120 \mathrm{MPa}$ at $20^{\circ} \mathrm{C}$. The w/b ratio was 0.15 .

Year 2011: Tuan et al. [26] incorporated rice husk grinds (RHA) as a substitute for silica fume into the mist. They used the particle packing model developed by Larrard [20] to optimize the granulometry of the mixture. They showed that as the average size of the RHA increases, the compressive strength decreases. They reached $150 \mathrm{MPa}$ with a maximum grain size of $8 \mu \mathrm{m}$ and $20 \%$ of that material with respect to the weight of the cement.

Year 2012: Hassan et al. [5] developed a methodology to determine the compressive strength, reaching $121.32 \mathrm{MPa}$ and 150.56 
$\mathrm{MPa}$ at 28 days with and without fibers respectively, using the design of mixtures of the University of Liverpool [25], which includes , in addition to cement, to SF and GGBS as binder materials. The ratio $w / b$ is 0.17 and that of $w / c$ is 0.24 . They used heat treatment in the curing water at $90^{\circ} \mathrm{C}$ for 48 hours and then at room temperature until the day of the test. Toledo et al. [27] obtained $160 \mathrm{MPa}$ of compressive strength, maximizing the compaction of the granular mixture, based on the distribution of the size of the grains, the specific gravity and the virtual density of packaging of the constituents of the mixture, as well as, the contribution of the type of cement (Bast furnace cement type III/40) and the content of chemical additives. They used Wollastonite and SF as mineral additives.

Year 2014: Yu et al. [6] produced and evaluated three densely compacted mixtures with low cement content, using the modified particle packing model of Andreasen \& Andersen. They reached 94.2 $\mathrm{MPa}$ at 28 days with the mixture with the highest amount of cement $\left(875 \mathrm{~kg} / \mathrm{m}^{3}\right)$ and $148.6 \mathrm{MPa}$ with the mixture that included $2.5 \%$ of short steel fibers, with the same amount of cement.

Year 2016: Wu et al. [28] achieved $118 \mathrm{MPa}$ at 28 days using 25\% silica fume, $a \mathrm{w} / \mathrm{b}$ ratio of 0.18 and a $\mathrm{w} / \mathrm{c}$ ratio of 0.21 . They studied different contents of silica fume within the mixture, demonstrating its important effect on the resistance to compression. Lampropoulos et al. [29] tested $100 \mathrm{~mm}$ cubes in compression, with a loading speed of $0.0007 \mathrm{~mm} / \mathrm{sec}$, reaching $164 \mathrm{MPa}$ at 28 days in the specimens that included $3 \%$ short steel fibers in the mixture and applying heat treatment of curing in water, initially at $90^{\circ} \mathrm{C}$ for three days and later at room temperature. Liu et al. [30] added to the mixed crushed basalt as coarse aggregate with diameters between 5 to $20 \mathrm{~mm}$ and river sand with a maximum size of 5 $\mathrm{mm}$. They achieved a compression resistance of $99.70 \mathrm{MPa}$ without fibers and $143.6 \mathrm{MPa}$ using $2.5 \%$ steel short fibers in $100 \mathrm{~mm}$ cubes side. They also worked with a $\mathrm{w} / \mathrm{b}$ ratio of 0.18 and varied, in four levels each, the amounts of coarse aggregate, superplasticizer and steel fibers. Kang et al. [31] investigated the compres- sive strength in 50-mm-side cubes, using, as binder materials, the cement and silica fume of zirconium. They also used additives to reduce autogenous shrinkage, steel fibers and hybrid fibers. The highest resistance in the hybrid specimens was obtained by combining $1.5 \%$ steel fibers with $0.5 \%$ polyvinyl fibers, obtaining in this case 147.49 MPa.

Year 2017: Lee et al. [32] developed compression and tensile strength studies in flat elements, tested cylinders for two types of mixture with and without fibers, reaching values of $127.38 \mathrm{MPa}$ without fibers and 157.46 MPa with fibers. Hoang and Fehling [33] determined that there are no significant changes in compressive strength or modulus of elasticity due to the inclusion of steel fibers in concrete mixtures, using cylindrical test bodies of $15 \mathrm{~cm}$ in diameter and $30 \mathrm{~cm}$ in height. They reached 216.66 MPa and 211.69 $\mathrm{MPa}$ without and with $1.5 \%$ fibers. Kahanji et al. [34] reached 97.20 $\mathrm{MPa}$ using $1 \%$ fiber with water curing at $20^{\circ} \mathrm{C}$ and $154.60 \mathrm{MPa}$ with water curing at $90^{\circ} \mathrm{C}$, both for 7 days, and subsequently stored in a humid room until the day of the test. Wu et al. [35] produced a mixture without fibers and five with fibers to evaluate the static and dynamic properties of the concrete subjected to compression, reaching 98.30 MPa and 143.6 MPa respectively. Alsalman et al. [36] reached 118.6 MPa without fibers and without heat treatment in curing, using local commercial materials.

\subsection{Mix design}

The mix design of UHPRC differs from traditional concrete by excluding coarse aggregate and using fine sand. It includes mineral additives that act as a microfiller, filling the small voids between particles, thus improving the interstitial zone and also reacting with calcium hydroxide to increase the final resistance. The superplasticizer is used as a chemical additive to improve workability and decrease the $w / b$ ratio that is generally less than or equal to 0.20 . In Table 1 we can see a summary of the mixture design used by some

\section{Table 1}

Comparison between mixture designs and compressive strength (28 days)

\begin{tabular}{|c|c|c|c|c|c|c|c|c|c|c|c|}
\hline \multirow{2}{*}{ Reference } & \multicolumn{6}{|c|}{$\left(\mathrm{kg} / \mathrm{m}^{3}\right)$} & \multirow{2}{*}{$w / b$} & \multirow{2}{*}{$w / c$} & \multirow{2}{*}{$\begin{array}{c}\% \\
\text { fibers }\end{array}$} & \multicolumn{2}{|c|}{ MPa } \\
\hline & Cement & GGBS & SF & w & Quartz & Sand & & & & $\mathbf{f}_{\mathrm{ck}}$ & $\mathrm{f}_{\mathrm{ck}}{ }^{*}$ \\
\hline Hassan [5] & 657 & 418 & 119 & 0 & 0 & 1051 & 0.15 & 0.28 & 2 & 151 & 121 \\
\hline $\mathrm{Yu}[6]$ & 875 & 0 & 44 & 0 & 0 & 1273 & 0.22 & 0.23 & 2.5 & 149 & 94 \\
\hline Habel [7] & 1050 & 0 & 275 & 0 & 0 & 730 & 0.14 & 0.18 & 6 & 168 & - \\
\hline Yang [8] & 657 & 430 & 119 & 0 & 0 & 1050 & 0.15 & 0.28 & 2 & 190 & - \\
\hline Bache [17] & 300 & 0 & 100 & 0 & 0 & 0 & 0.19 & 0.25 & 0 & 0 & 130 \\
\hline Larrad [20] & 1081 & 0 & 334 & 0 & 0 & 813 & 0.14 & 0.18 & 0 & 238 & 165 \\
\hline Rossi [23] & 1050 & 0 & 268 & 0 & 0 & 514 & 0.16 & 0.20 & 5 & 205 & - \\
\hline $\operatorname{Lim}[24]$ & 543 & 0 & 80 & 0 & 0 & 1242 & 0.21 & 0.24 & 1.5 & 121 & - \\
\hline Graybeal [25] & 710 & 0 & 230 & 0 & 210 & 1020 & 0.14 & 0.15 & 2 & 193 & 126 \\
\hline Thanh [26] & 657 & 418 & 119 & 0 & 0 & 1051 & 0.15 & 0.28 & 2.5 & 186 & 144 \\
\hline Toledo [28] & 1011 & 0 & 58 & 76 & 0 & 962 & 0.17 & 0.16 & 2 & 162 & - \\
\hline Wu [29] & 863 & 315 & 216 & 0 & 0 & 1079 & 0.18 & 0.21 & 2 & - & 118 \\
\hline Lampropoulos [30] & 657 & 418 & 119 & 0 & 0 & 1051 & 0.15 & 0.28 & 3 & - & - \\
\hline Hoang [34] & 795 & 0 & 169 & 0 & 198 & 971 & 0.16 & 0.24 & 1.5 & 212 & 217 \\
\hline Kahanji [35] & 967 & 0 & 251 & 0 & 0 & 675 & 0.20 & 0.25 & 1 & 155 & - \\
\hline Wu [36] & 472 & 315 & 262 & 0 & 0 & 1049 & 0.17 & 0.38 & 2 & 144 & 98 \\
\hline
\end{tabular}

${ }^{*} \mathrm{f}_{\mathrm{ck}}$ : Compression strength without using fibers in the mixture; $\mathrm{W}$ : Wollastonite microfibers. 
authors and compare the values of compression strength obtained with and without the use of fibers in the mixture. When the mixture includes fibers, the concrete is called Ultra High Performance Fiber Reinforced Concrete (UHPFRC). In this study we will work without fibers, that is, with UHPRC.

\section{Procedure}

\subsection{Definition of experimental program variables}

To produce economically sustainable UHPRC we must study the proportions of the industrial waste to be used in the mix design, as well as compare the evolution of the resistance over time, that is, determine the magnitude of the accelerated resistance produced by the heat treatment at early ages, to compare it with economical curing processes at room temperature.

Additionally, in the review of the literature it was clearly observed that to achieve concretes with ultra-high compressive strength we must (i) reduce the $w / c$ ratio, (ii) use a w/b ratio between $0.15-0.20$ and (iii) increase the degree of compaction of the mixture. The first aspect involves an increase in the heat of hydration of the cement with possible consequences of thermal shrinkage cracking. The second aspect could increase the amount of voids between the cement particles and the aggregate and thus produce low strength. The third aspect requires densifying the concrete matrix by occupying the possible voids with different particle sizes and applying mechanical vibration.

For these reasons, the use of mineral additives, such as silica fume or SF and blast furnace slag or GGBS, are included in the mixture. Both minerals can be combined with the cement and react with the water to produce the durable $\mathrm{C}-\mathrm{S}-\mathrm{H}$, they can also control the amount of heat of hydration and prevent thermal cracking. The SF is composed of very fine particles that can occupy the interstitial zone and together to the GGBS increase the density of the mixture, with this, the water demand will also be increased, therefore the incorporation of a chemical additive to improve the workability without increase the ratio $\mathrm{w} / \mathrm{b}$ is necessary. For this reason are consid-

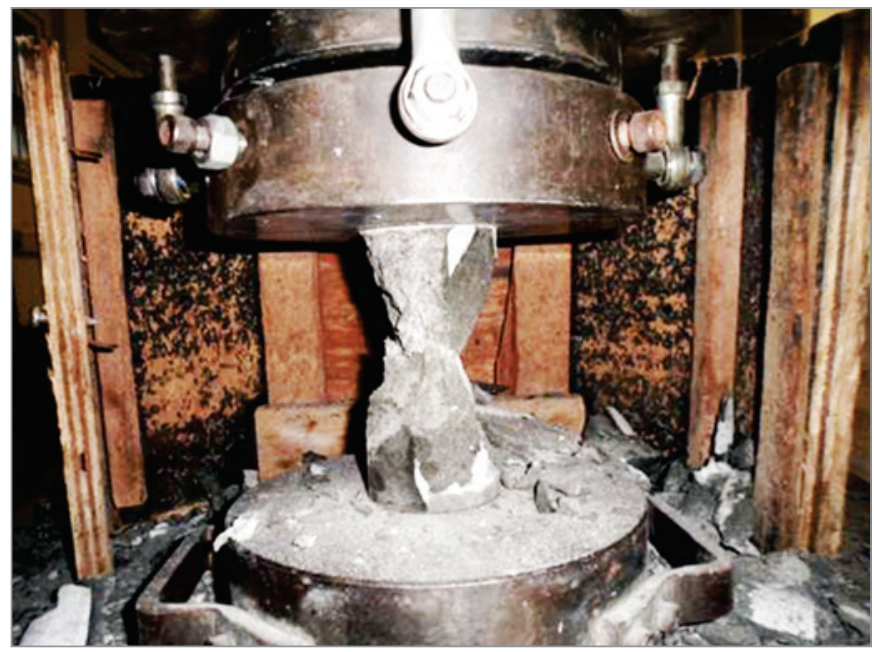

Figure 1

Uniaxial compression test ered as variables or controllable factors in our experimental study those related to: (i) sustainability, for which we will work with different quantities of industrial waste as partial substitutes for the quantity of cement; (ii) the densification of the matrix, for which different granulometries of the blast furnace slag will be used; (iii) the type of curing, for which we will apply heat treatment in the curing to half of the specimens and the other part will be cured at room temperature, with this the gain of resistance in early ages can be evaluated; and (iv) the compressive strength at different ages curing.

\subsection{Materials}

The binder materials used in the mixture are constituted by: (i) Portland CP V ARI national cement with high initial strength, (ii) blast furnace slag (GGBS) donated by the company ArcelorMittal Tubarão do Estado do Espíritu Santo, from which the batch of material for the tests was obtained following the stipulations of the norm NBR NM 26 [41], (iii) silica fume (SF) is of the ND SILMIX type manufactured by Dow Corning Metais do Para Indústria e Comércio Ltda, Pará-Brasil. The mixture has a unique aggregate constituted by silica sand (SS), with maximum grain size of $0.30 \mu \mathrm{m}$. A polycarboxylate solution in aqueous medium (ViscoCrete 3535 ), supplied by the company SIKA, which adjusts the workability of the concrete and is mixed with water to be placed in the mixture, was used as a superplasticizing additive.

\subsection{Mix design}

The mixtures used in this study are shown in Table 4. Those three designs were combined with three different sizes of the GGBS, to get nine mix designs to produce concrete with ultra-high strength and evaluate its compressive strength. The one developed by Thanh [25] identified as UHPRC-2 was used as the base mixture design, from which the individual amounts of binders were varied, maintaining the $\mathrm{w} / \mathrm{b}$ ratio constant, and the superplasticizer was used in a proportion of $3.35 \%$ of the total weight of the binders.

\subsection{Manufacture of mixtures}

Nine designs of mixture will be concreted to be tested under uniaxial compression loads at 7, 14 and 28 days. Two treatments of curing in water will be applied, the first with thermal cure (identified as CTT) which consists of immersing the test bodies for 24 hours in a thermal bath at $60{ }^{\circ} \mathrm{C}$ and later at a temperature of $20{ }^{\circ} \mathrm{C}$ $\pm 3{ }^{\circ} \mathrm{C}$, and the second without thermal cure (identified as STT) which will be done by immersing the specimens in water at room temperature $\left(20^{\circ} \mathrm{C} \pm 3{ }^{\circ} \mathrm{C}\right)$ until the day of the test. In the mixing process, the materials must first be weighed and placed in a mortar mixer in the following order: silica fume, cement, blast furnace slag and silica sand. The dry materials are mixed for approx. 5 minutes before placing the superplasticizer previously mixed with the water. All materials must be mixed for approx. 10 additional minutes, until the mixture becomes a wet concrete paste. In this state the mixture for the UHPRC is considered ready, and then proceeds to empty it into cylindrical molds. These molds are $5 \mathrm{~cm}$ in diameter and 10 $\mathrm{cm}$ in height, which, once full, are compacted on a vibrating table for 1 minute. The test bodies are stored and covered with a plastic 


\section{Table 2}

Yield stress and viscosity of the pastes with varying contents of grinding dust (GD)

\begin{tabular}{|c|c|c|c|c|}
\hline Designation & Control factor & Level 1 & Level 2 & Level 3 \\
\hline A & Age of the sample & 7 day & 14 day & 28 day \\
\hline B & Maximum size GGBS & $850 \mu \mathrm{m}$ & $1700 \mu \mathrm{m}$ & $1180 \mu \mathrm{m}$ \\
\hline \multirow[t]{4}{*}{ C } & Type of mix & UHPRC-1 & UHPRC-2 & UHPRC-3 \\
\hline & Cement: & $50 \%$ & $55 \%$ & $65 \%$ \\
\hline & GGBS: & $45 \%$ & $35 \%$ & $15 \%$ \\
\hline & SF: & $5 \%$ & $10 \%$ & $20 \%$ \\
\hline D & Type of curing & Without heat treatment & Without heat treatment & - \\
\hline
\end{tabular}

blanket for 24 hours, after that time, they are divided into two parts to apply the different types of curing. The first curing consists of storing them in water at room temperature until the day of the test. The second curing consists of placing them in a thermal bath for 24 hours at a temperature of $60^{\circ} \mathrm{C}$, and later storing them in water at room temperature until the day of the test, taking care that the specimens do not suffer thermal shock.

\subsection{Preparation of the specimens and compression test}

The uniaxial compression test was performed on the 162 specimens (see Figure 1), manufactured in steel molds of $5 \mathrm{~cm}$ in diameter by $10 \mathrm{~cm}$ in height, according to the criteria specified in the ABNT NBR7215 standard [42]. Previously the upper and lower faces of the cylinders are leveled by mechanical means, using a grinding machine, and the height of each test body is measured to verify the need to apply some correction factor in the resistance as stipulated in item 6.1. 2 Table 2 of the ABNT standard NBR5739 [43].

The specimens will be tested at 7, 14 and 28 days of curing in a hydraulic press with a capacity of $2000 \mathrm{kN}$, at a loading rate of 1 $\mathrm{MPa} / \mathrm{sec}$ until the last load. To decrease the experimental vari-

\section{Table 3}

Degrees of freedom required

\begin{tabular}{|c|c|}
\hline Designation & Degrees of freedom \\
\hline$A$ & 2 \\
\hline B & 2 \\
\hline C & 2 \\
\hline $\mathrm{D}$ & 1 \\
\hline$A \times B$ & 4 \\
\hline$A \times C$ & 4 \\
\hline$A \times D$ & 2 \\
\hline$B \times C$ & 4 \\
\hline$B \times D$ & 2 \\
\hline$C \times D$ & 2 \\
\hline$A \times B \times C$ & 8 \\
\hline$B \times C \times D$ & 4 \\
\hline$C \times D \times A$ & 4 \\
\hline$D \times A \times B$ & 4 \\
\hline$A \times B \times C \times D$ & 8 \\
\hline Média general & 1 \\
\hline Total & 52 \\
\hline
\end{tabular}

ance, materials from the same batch and the same equipment will be used for the manufacture and testing of the test pieces.

\subsection{Analysis of the data}

A practical strategy widely used to analyze the results of tests of resistance to compression of concrete is the factorial arrangement, in which different treatments are defined to be compared. In the design of treatments, the controllable factors, their levels and the combination between them are selected. The experimental design indicates the way in which the treatments are randomized and the way to control the natural variability of them.

In this study a complete factorial arrangement was defined. The experimental design was developed through an analysis of variance using ANOVA, which is the statistical treatment most commonly applied to experimental results to determine if any controllable factor or interaction between factors have a significant influence on the response variable, with a low percentage of uncertainty, Ayan et al. [37], Mucteba U. [38], Yoon et al. [39], Mukharjee et al. [40]. Four controllable factors were established in the design of the treatments: (i) age of the sample, (ii) maximum size of the GGBS (iii) type of mixture (UHPRC-1, UHPRC-2, UHPRC-3) and (iv)) type of curing, identified with the letters $A, B, C$ with three levels of control and $\mathrm{D}$ with two levels of control respectively, which leads to 54 experiments that include all the possible combinations that should be introduced in the design, see Table 2.

Three repetitions were made in each case to make a total of 162 experiments. The total number of degrees of freedom resulting is 52 , which are indicated in Table 3.

The $\mathrm{w} / \mathrm{b}$ ratio remained fixed at 0.15 and the $\mathrm{w} / \mathrm{c}$ ratio was 0.31 for UHPRC-1, 0.28 for UHPRC-2 and 0.24 for UHPRC-3. The amount of silica sand, superplasticizer and water remained constant. The three types of mixtures are differentiated by the percentages of binders in each case, as observed in Table 2.

Table 4

Mixture designs for UHPRC $\left(\mathrm{kg} / \mathrm{m}^{3}\right)$

\begin{tabular}{cccc}
\hline Material & UHPRC-1 & UHPRC-2 & UHPRC-3 \\
\hline Cement & 597 & 657 & 776 \\
GGBS & 537 & 418 & 179 \\
SF & 60 & 119 & 239 \\
SS & 1051 & 1051 & 1051 \\
Superplastificante & 40 & 40 & 40 \\
Water & 185 & 185 & 185 \\
\hline
\end{tabular}


Table 5

Average compression strength of the UHPRC (MPa) for 7, 14 and 28 days

\begin{tabular}{|c|c|c|c|c|c|c|c|c|c|}
\hline \multirow{3}{*}{$\begin{array}{l}\text { A } \\
\text { B } \\
\text { C }\end{array}$} & \multicolumn{9}{|c|}{ A1: 7 days } \\
\hline & \multicolumn{3}{|c|}{$\mathrm{B} 1: 850 \mu \mathrm{m}$} & \multicolumn{3}{|c|}{ B2: $1700 \mu \mathrm{m}$} & \multicolumn{3}{|c|}{ B3: $1180 \mu \mathrm{m}$} \\
\hline & $\mathrm{Cl}$ & $\mathrm{C} 2$ & C3 & $\mathrm{Cl}$ & $\mathrm{C} 2$ & C3 & $\mathrm{Cl}$ & $\mathrm{C} 2$ & C3 \\
\hline \multirow{2}{*}{ D } & 51 & 84 & 106 & 63 & 81 & 89 & 56 & 74 & 119 \\
\hline & 60 & 95 & 93 & 70 & 68 & 86 & 78 & 77 & 95 \\
\hline
\end{tabular}

\begin{tabular}{|c|c|c|c|c|c|c|c|c|c|}
\hline \multirow{3}{*}{$\begin{array}{l}\text { A } \\
\text { B } \\
\text { C }\end{array}$} & \multicolumn{9}{|c|}{ A2: 14 days } \\
\hline & \multicolumn{3}{|c|}{$\mathrm{B} 1: 850 \mu \mathrm{m}$} & \multicolumn{3}{|c|}{ B2: $1700 \mu \mathrm{m}$} & \multicolumn{3}{|c|}{ B3: $1180 \mu \mathrm{m}$} \\
\hline & $\mathrm{Cl}$ & $\mathrm{C} 2$ & C3 & $\mathrm{Cl}$ & $\mathrm{C} 2$ & C3 & $\mathrm{Cl}$ & $\mathrm{C} 2$ & C3 \\
\hline \multirow{2}{*}{ D } & 58 & 104 & 120 & 64 & 65 & 95 & 61 & 63 & 125 \\
\hline & 67 & 97 & 96 & 82 & 85 & 92 & 84 & 99 & 112 \\
\hline
\end{tabular}

\begin{tabular}{|c|c|c|c|c|c|c|c|c|c|}
\hline \multirow{3}{*}{$\begin{array}{l}\text { A } \\
\text { B } \\
\text { C }\end{array}$} & \multicolumn{9}{|c|}{ A3: 28 days } \\
\hline & \multicolumn{3}{|c|}{$\mathrm{B1}: 850 \mu \mathrm{m}$} & \multicolumn{3}{|c|}{ B2: $1700 \mu \mathrm{m}$} & \multicolumn{3}{|c|}{ B3: $1180 \mu \mathrm{m}$} \\
\hline & $\mathrm{Cl}$ & $\mathrm{C} 2$ & C3 & $\mathrm{Cl}$ & $\mathrm{C} 2$ & $\mathrm{C} 3$ & $\mathrm{Cl}$ & $\mathrm{C} 2$ & $\mathrm{C} 3$ \\
\hline \multirow{2}{*}{ D } & 72 & 113 & 138 & 46 & 98 & 122 & 90 & 102 & 135 \\
\hline & 81 & 116 & 122 & 94 & 106 & 115 & 110 & 100 & 117 \\
\hline
\end{tabular}

\section{Results and discussions}

\subsection{Compression resistance test}

For each uniaxial compression test at 7, 14 and 28 days of curing at least three specimens were tested, their average values are shown in Table 5. In each pair of data reflected, the value in the upper line corresponds to the specimen with thermal treatment and the value in the lower line corresponds to the specimen without thermal treatment in the curing. B1, B2 and B3 correspond to the granulometry types of the GGBS for $850 \mu \mathrm{m}, 1700 \mu \mathrm{m}$ and $1180 \mu \mathrm{m}$ respectively, and the mixing types $\mathrm{C} 1, \mathrm{C} 2$ and $\mathrm{C} 3$ correspond to the concrete UHPRC-1, UHPRC-2 and UHPRC-3 respectively. The UHPRC-3 mixture showed the highest resistance values for all ages. The highest average value of compression resistance was $138 \mathrm{MPa}$, which corresponds to the mixture with thermal treatment of curing and with a maximum slag size of $850 \mu \mathrm{m}$.

\subsection{Analysis of residual deviations}

The maximum relative deviation was calculated by dividing the

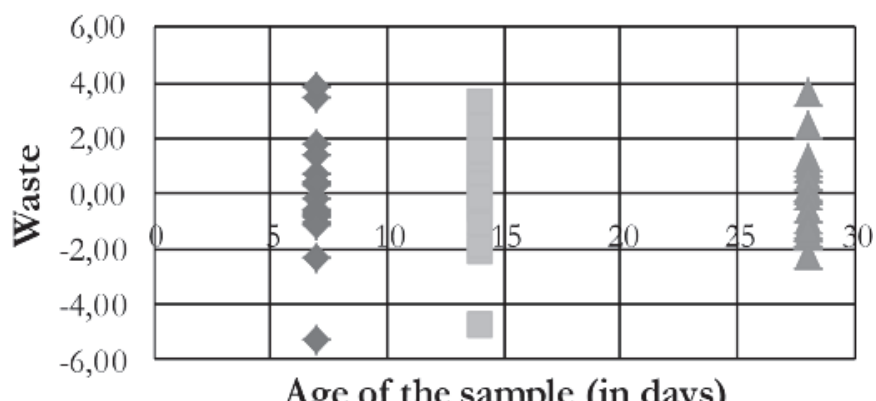

\section{Figure 2}

Age of the sample \& residual deviations for the UHPRC-1 mix absolute value of the difference between the average resistance and the individual resistance that is further away from the mean, by the average resistance and multiplying this value by 100 , ABNT NBR7215 [42].

In cases where the maximum relative deviation exceeded $6 \%$, the

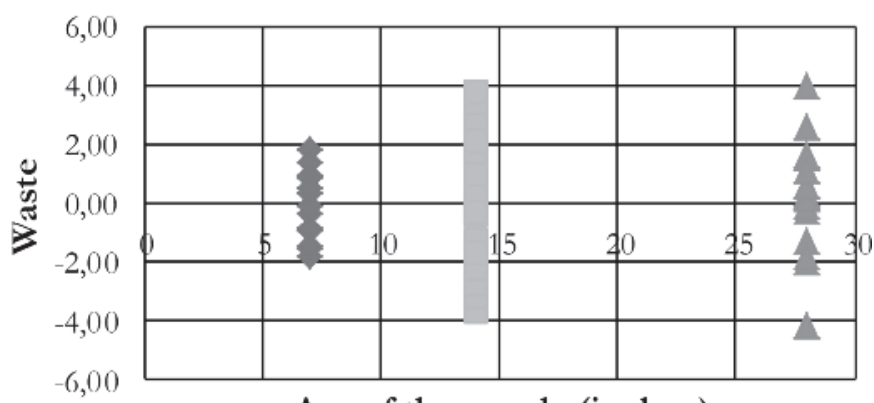

Age of the sample (in days)

Figure 3

Age of the sample \& residual deviations for the UHPRC-2 mix

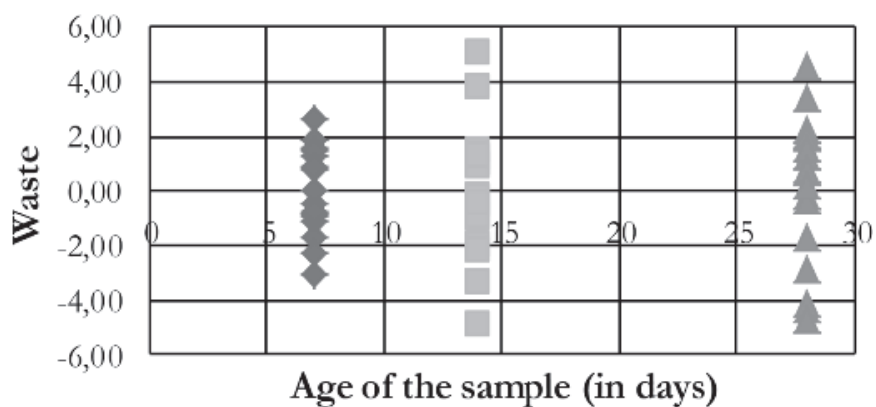

Figure 4

Age of the sample \& residual deviations for the UHPRC-3 mix 


\section{Table 6}

ANOVA analysis of variance results

\begin{tabular}{|c|c|c|c|c|c|c|}
\hline Control factor & Source & $S Q$ & GDL & $\mathrm{MQ}$ & Teste F & Probability \\
\hline Age of the sample & $A$ & 16521 & 2 & 8260 & 1481 & $3.1 \mathrm{E}-79$ \\
\hline Maximum size GGBS & B & 2965 & 2 & 1482 & 266 & $1.93 \mathrm{E}-42$ \\
\hline Type of mix & C & 39614 & 2 & 19807 & 3552 & 2.97E-99 \\
\hline \multirow[t]{14}{*}{ Type of curing } & $\mathrm{D}$ & 639 & 1 & 639 & 115 & $1.14 \mathrm{E}-18$ \\
\hline & $A B$ & 185 & 4 & 46 & 8 & $6.99 \mathrm{E}-06$ \\
\hline & $A C$ & 444 & 4 & 111 & 20 & $2.61 \mathrm{E}-12$ \\
\hline & $A D$ & 322 & 2 & 161 & 29 & $9.16 \mathrm{E}-11$ \\
\hline & $B C$ & 5414 & 4 & 1354 & 243 & $5.27 \mathrm{E}-53$ \\
\hline & $\mathrm{BD}$ & 793 & 2 & 396 & 71 & 2.00E-20 \\
\hline & $C D$ & 6961 & 2 & 3480 & 624 & $4.58 \mathrm{E}-60$ \\
\hline & $A B C$ & 2502 & 8 & 313 & 56 & $5.44 \mathrm{E}-35$ \\
\hline & $B C D$ & 658 & 4 & 164 & 29 & $1.44 \mathrm{E}-16$ \\
\hline & CDA & 721 & 4 & 180 & 32 & $1.08 \mathrm{E}-17$ \\
\hline & DAB & 1426 & 4 & 356 & 64 & 1.32E-27 \\
\hline & $A B C D$ & 1368 & 8 & 171 & 31 & $1.59 \mathrm{E}-24$ \\
\hline & Mistake & 602 & 108 & 6 & - & - \\
\hline & TOTAL & 81135 & 161 & - & - & - \\
\hline
\end{tabular}

trial was repeated for all ages. The residual deviations for each type of concrete can be observed in Figures 2, 3 and 4. In each graph the variability of the compressive strength is shown at 7,14 and 28 days with respect to the average for each type of UHPRC mixture. We noticed that the mixtures UHPRC-2 and 3 present less dispersion at seven days, the mixture UHPRC-2 at fourteen and the mixture UHPRC-1 at twenty-eight days of curing. Some values are more distant than the average, however, in all cases, the deviations are within the range allowed by the ABNT NBR7215 standard [42].

\subsection{Analysis of variance and comparison of means}

The results of the analysis of variance using ANOVA are shown in Table 6, in which four controllable factors were analyzed and eleven interactions were generated.

For all cases the value of the probability indicated by the distribution $\mathrm{F}$ is less than $1 \%$, this means that all the controllable factors have significant influence on the response variable, which in our case is the resistance to compression, with a confidence level of more than $99 \%$. In other words, the differences in the response variable are due to the influence of the controllable factors and not to the experimental error.

The contribution percentage of each controllable factor on the compressive strength can be visualized in Figure 5. Those values were calculated by dividing each square sum by the total of square sums and then multiplying by 100 .

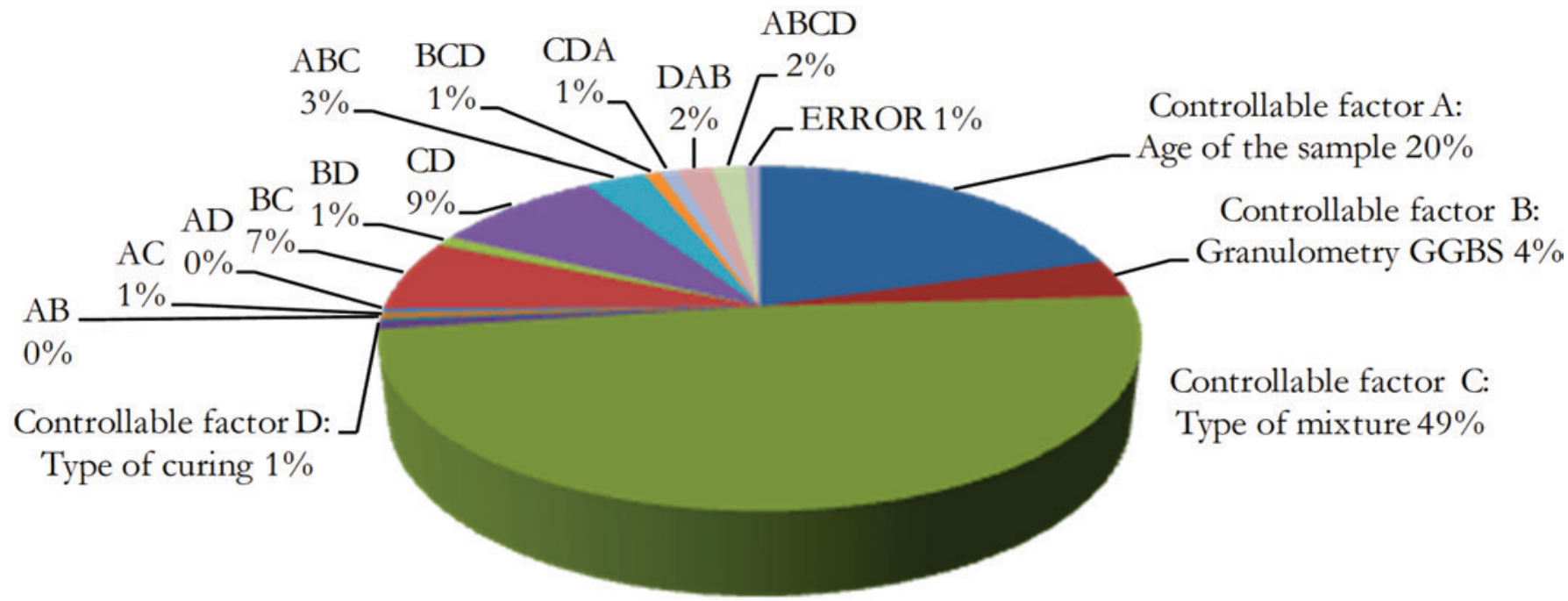

Figure 5

Contribution of the controllable factors and their interactions in the compressive strength 


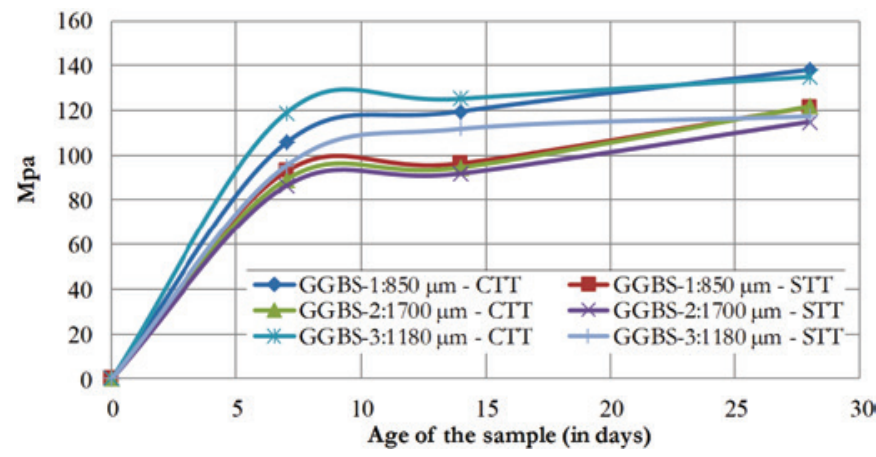

\section{Figure 6}

\section{Compressive strength UHPRC-3 depending} on the age of the sample

High resistance was obtained with thermal treatment in the curing in [12-15, 20-22, 24 and 28], however, in our study the type of curing showed to have $1 \%$ of importance on the resistance to compression for the designs of mixture studied. In the references mentioned above, the temperature used was greater than $60{ }^{\circ} \mathrm{C}$ and for a period of time greater than 24 hours. At the date of conducting the experiments in this study, limitations in the equipment of the laboratory prevented the application of a thermal treatment closer to that commonly used in the literature. Possibly submerging the specimens in water at $60^{\circ} \mathrm{C}$ for 24 hours did not sufficiently accelerate the compressive strength.

Significant differences in compressive strength with or without thermal treatment during curing were not achieved, as occurred in [8, 24, 25, 34]. In [17, 19, 24 and 36], results similar to ours were found using a significant amount of silica fume, superplasticizer and without the use of heat treatment.

Since all the controllable factors have significant influence on the compressive strength of the UHPRC, it is possible to perform an analysis of means in any of them. There are significant differences between the means of each level, as it could be observed in Table 5 , so when ordering them in increasing order we can verify if the interval between them exceeds the Decision Limit (LD), where LD is equal to three times the standard deviation of the sample means. This procedure is called multiple means comparison, which will be

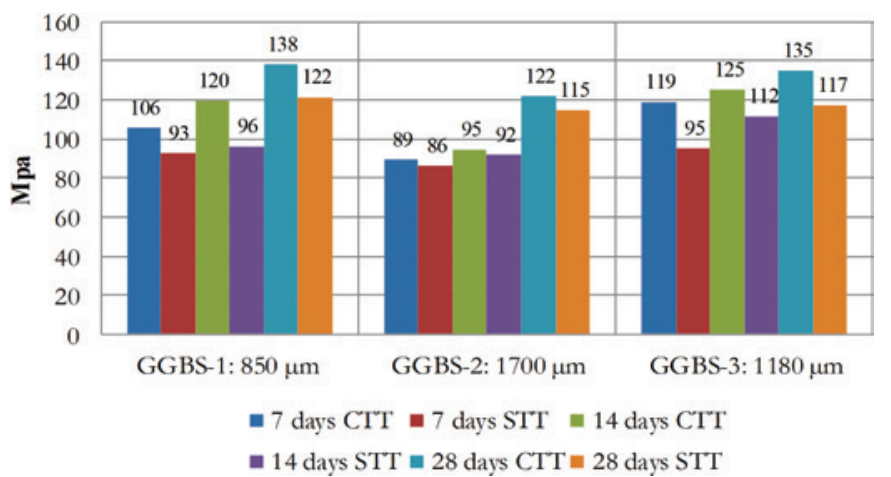

Figure 7

Compressive strength UHPRC-3 depending on the maximum size of GGBS developed next, focusing mainly on the results obtained for the UHPRC-3 mixture design that gave the best results and the highest resistance.

To compare the means of the controllable factor $A$ (age of the sample) and of its interactions $A B, A C, A D$ we will fix the levels of $B, C$ and $D$. Thus in Figure 6 we can see how the compressive strength varies with the age of the sample, for the three sizes of slag, with and without thermal treatment in the curing. The highest values of the compressive strength were obtained after 28 days of curing with thermal treatment, the results were 138, 122 and $135 \mathrm{MPa}$ for GGBS with a maximum size of 850,1700 and $1180 \mu \mathrm{m}$ respectively. The resistance results without heat treatment were 122, 115 and $117 \mathrm{MPa}$ for GGBS with a maximum size of 850,1700 and $1180 \mu \mathrm{m}$ respectively.

To compare the means of the controllable factor $\mathrm{B}$ (granulometry of the GGBS) and its interactions BA, BC, BD we will fix the levels of $A, C$ and $D$. Thus in Figure 7 we can see how the compressive strength varies with the granulometry of the GGBS, for the three ages of the sample, with and without heat treatment in the curing. The highest resistance values were 138, 122 and $135 \mathrm{MPa}$ for GGBS-850, GGBS-1700 and GGBS-1180 $\mu \mathrm{m}$ respectively, after 28 days of curing with heat treatment. Without heat treatment the results were 122,115 and $117 \mathrm{MPa}$ respectively.

To compare the means of the controllable factor $C$ (type of mixture) and its interactions $C A, C B, C D$ we will set the levels of $A, B$ and $D$. Thus in Figure 8 we can see how the compression resistance varies with the type of UHPRC mixture, for the three ages of the sample, with and without heat treatment in the curing. For mixtures UHPRC-1 and UHPRC-2, the highest values of compressive strength were 81 and $116 \mathrm{MPa}$ respectively, after 28 days of curing without heat treatment. For the UHPRC-3 mixture the highest value reached was $138 \mathrm{MPa}$ at 28 days with thermal treatment in the curing.

To compare the means of the controllable factor $D$ (type of curing) and its interactions DA, DB, DC we will set the levels of $A, B$ and C. Thus in Figure 9 we can see how the compression resistance varies with the type of cured, for the three ages of the sample and the three types of mixture. In this case we will reflect the results for the granulometry of the slag GGBS-850 $\mu \mathrm{m}$ with which the highest resistance was obtained. After 7 days of curing with heat treatment, the UHPRC-1, 2 and 3 mixtures reached respectively 72,74

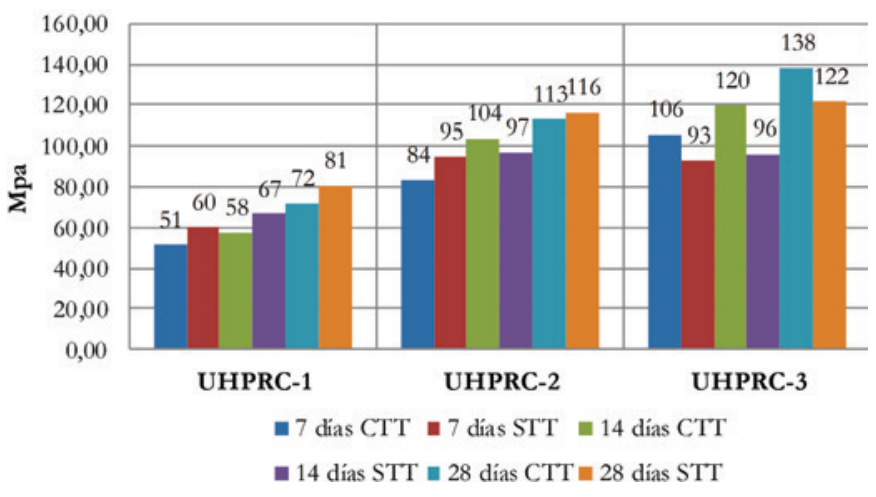

Figure 8

Compressive strength for the three types of mixture 


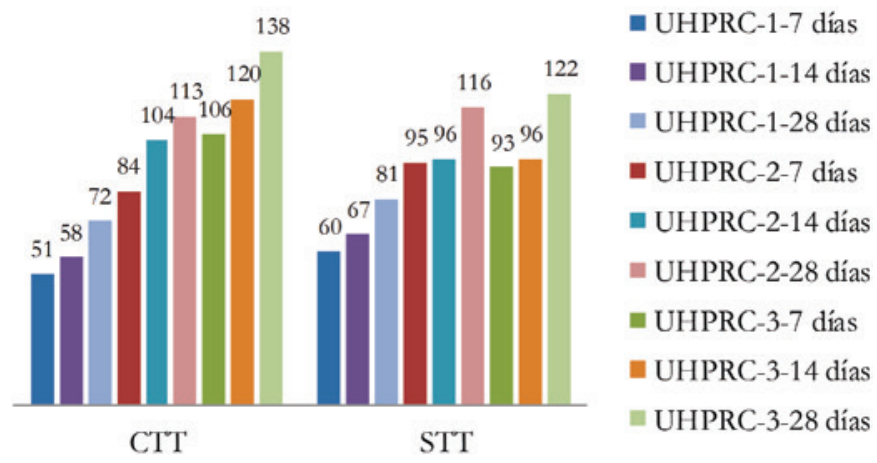

Figure 9

Compression strength values for GGBS-850 $\mu \mathrm{m}$ with the type of cure

and $76 \%$ of the resistance at 28 days; without thermal treatment they reached 74,81 and $76 \%$. After 14 days of curing with heat treatment, the UHPRC-1, 2 and 3 mixtures increased the resistance of the 7 days respectively by 12,24 and $13 \%$; without heat treatment they increased by 11,2 and $4 \%$. After 28 days of curing with heat treatment, the UHPRC-1, 2 and 3 mixtures increased the resistance of the 7 days respectively by 40,35 and $31 \%$; without heat treatment they increased by 34,23 and $31 \%$.

\section{Conclusions}

The mix design that showed the highest values of compressive strength was the UHPRC-3, after 28 days of curing, using GGBS with a maximum size of $850 \mu \mathrm{m}$ and using heat treatment. The results were 136, 137 and $142 \mathrm{MPa}$, with which an average resistance of $138 \mathrm{MPa}$ was obtained. Without heat treatment during curing, the highest average resistance was $122 \mathrm{MPa}$.

After 7 days of curing, at least $70 \%$ of the compressive strength of the 28 days was reached. On average, the gain in resistance from 7 to 28 days was 32,26 and $44 \%$ for UHPRC-1, 2 and 3 respectively.

For a GGBS of maximum size $850 \mu \mathrm{m}$, the mixing designs $U H-$ PRC-1 and UHPRC-2 did not show significant differences in the results with and without heat treatment in the curing. The UHPRC-1 mixture had to be repeated several times because the test bodies submerged in thermal cure cracked. These mixtures contain the lowest percentages of silica fume and GGBS, so we can presume that a large amount of the heat of hydration was generated and possible thermal cracking prevented the development of resistance at an early age. For UHPRC-3 greater differences between curing treatments were found, however, they did not exceed $20 \%$. The behavior described above influenced the low contribution percentage of that variable (type of curing) on the resistance to compression. For a GGBS with a maximum size of $1700 \mu \mathrm{m}$ and $1180 \mu \mathrm{m}$, a better behavior was obtained in the specimens without heat treatment in the curing. The resistance at 7 days was on average $25 \%$ lower in the specimens that included 24 hours of thermal treatment in the curing. Therefore, the larger the size of the slag, the thermal treatment seems to have negatively influenced the gain of resistance at early ages
Including heat treatment in curing accelerates the compressive strength of concrete at early ages, however, in our study, the type of curing proved to be $1 \%$ important on the compressive strength for the mixture designs studied. Therefore, in this case, the manufacture of the mixture without heat treatment in curing is a better option from the economic point of view.

It is recommended to extend the levels of the controllable factor $D$ referring to the type of curing, to study different types of heat treatment and to determine if a higher temperature or a longer time of exposure to heat can differentiate, more accentuated, the gain of resistance to compression at early ages.

The mix design recommended in this study is the UHPRC-3, using $65 \%$ CP-V cement, $15 \%$ GGBS cement with a maximum size of $850 \mu \mathrm{m}, 20 \%$ silica fume. Use fine sand as an aggregate, with a maximum size of $600 \mu \mathrm{m}$. Include running water and SIKA superplasticizer or similar.

\section{Acknowledgments}

The authors would like to thank the Coordination of Aperfeiçoamento de Pessoal de Nível Superior (CAPES), the Laboratory for Structural Models and Tests (LEME-UFRGS), mainly to the technicians Eurípedes Martins Fontes and Edgar Wallace Pereira. The authors also wish to thank the company AcerloMittalTubarão and SIKA-Brasil for the donation of research material.

\section{References}

[1] Fehling, E.; Schmidt, M.; Walraven, T.; Leutbecher, T.; Frohlich, S. Ultra High Performance Concrete UHPC Fundamentals, Design, Examples. First Edition, 2014, 188 p. http://www. wiley.com/WileyCDA/WileyTitle/productCd-3433030871.html

[2] Doo-Yeol Yoo, Young-Soo Yoon. A Review on Structural Behavior, Design, and Application of Ultra High Performance Fiber Reinforced Concrete. International Journal of Concrete Structures and Materials, v.10, n.2, 2016; p.125-142. https:// link.springer.com/article/10.1007/s40069-016-0143-x

[3] Tanaka, Y., Musya, H., Ootake, A. et al. Design and Construction of Sakata-Mirai Footbridge Using Reactive Powder Concrete. In: Proc. Of $1^{\text {st }}$ fib Congress Concrete Structure in the 21 st Century, Osaka, Japan, 2002, v.1, p.103-104.

https://structurae.net/structures/sakata-mirai-footbridge

[4] UNSTAT, Greenhouse gas emissions by sector (absolute values). United Nation Statistics Division. https://unstats. un.org/unsd/environment/air_greenhouse_emissions $\% 20$ by $\% 20$ sector.htm

[5] Hassan, A.; Jones, S.; Mahmud, G. Experimental test methods to determine the uniaxial tensile and compressive behavior of ultra-high performance fiber reinforced concrete (UHPFRC). Journal Construction and Building Materials, v.37, 2012; p.874-882. http://www.sciencedirect.com/ science/article /pii/S0950061812002322

[6] Yu, R.; Spiesz, P.; Brouwers, H. Mix design and properties assessment of Ultra High Performance Fiber Reinforced Concrete (UHPFRC). Journal Cement and Concrete Research, v.56, 2014; p.29-39. http://www.sciencedirect. com/science/article/pii/S0008884613002275 
[7] Habel, K.; Viviani, M.; Denarié, E.; Brühwiler, E. Development of the mechanical properties of an Ultra-High Performance Fiber Reinforced Concrete (UHPFRC). Journal Cement and Concrete Research, v.36, 2006; p.1362-1370. https://www. researchgate.net/publication/223459609

[8] Yang, S.L.; Millard, S.G.; Soutsos, M.N.; Barnett, S.J.; Le, T.T. Influence of aggregate and curing regime on the mechanical properties of ultra-high performance fiber reinforced concrete (UHPFRC). Journal Construction and Building Materials, v.26, n.6, 2009; p.2291-2298. http://www. sciencedirect.com /science/article/pii/S0950061808003449

[9] EMMA.http://minhateca.com.br/clubedoconcreto/ emma+elkem,674040748.rar(archive)

[10] Feret, René. Sur la Compacité des mortiers hydrauliques. Annals des Ponts et Chaussées, 1894.

[11] Reinhardt, H. W. Otto Graf's research on concrete roads-A retrospective view. Journal Otto Graf. Annual Journal on Research and Testing of Materials, v.14, 2003; p.9-19. https://www.mpa.uni-stuttgart.de/publikationen/otto_graf_ journal/ogj2003/beitrag_reinhardt.pdf

[12] Freyssinet, Eugene. https://structurae.info/personnes/ eugene-freyssinet

[13] Yudenfreund, M.; Odler, I.; Brunauer, S. Hardened Portland cement pastes of low porosity I. Materials and experimental methods. Journal Cement and Concrete Research, v.2, 1972; p.313-330. http://www.sciencedirect.com/science/ article/pii/0008884672900737

[14] Roy, D.; Gouda, G.; Bobrowsky, A. Very high strength cement pastes prepared by hot pressing and other high pressure techniques. Journal Cement and Concrete Research, v.2, 1972; p.349-366. http://www.sciencedirect.com/science/ article/pii/0008884672900750

[15] Roy, D. and Gouda, G. High strength generation in cement pastes. Journal Cement and Concrete Research, v.3, 1973; p.807-820. http://www.sciencedirect.com/science/article/ pii/0008884673900136

[16] Birchall, J.; Howard, A.; Kendall, K. Flexural strength and porosity of cements. Journal Nature Publishing Group, v.289, 1981; p.388-390. https://www.nature.com/nature/ journal/v289/n5796/pdf/289388a0.pdf

[17] Bache, H. H. Densified cement ultra-fine particle-based materials. In Proceedings of the 2 nd international conference on superplasticizers in concrete, Ottawa, Canada, 1981, p. 33. https://ntrl.ntis.gov/NTRL/dashboard/searchResults/ titleDetail/DE93500154.xhtml

[18] Lankard, D.; and Lease, D. Refractarios monolíticos precolados altamente reforzados. Journal of the American Ceramic Society, bulleting 61, 1982; p.728. http://boletines. secv.es/upload/20120509120356.z19832202.pdf

[19] Hjorth, L.; Alford, N.; Mangabhai, R.; Hirsch, P.; Moir, G.; Jefferis, S.; Blundell, R.; Kelly, A.; Defosse, C.; Sing, K.; Massazza, F.; Bensted, J. Journal Philosophical Transactions of the Royal Society of London. Series A - Mathematical and Physical Sciences, v.310, n. 1511, 1983; p.167-173.

[20] Larrard, F.; Sedran, T. Optimization of Ultra-HighPerformance Concrete by the use of a packing model. Journal Cement and Concrete Research, v.24, n.1, 1994; p.997-1009. http://www.sciencedirect.com/science/article/ pii/0008884694900221

[21] Richard, P., and Cheyrezy, M. Composition of reactive powder concretes. Journal Cement and Concrete Research, v.25, 1995; p.1501-1511. https://www.researchgate.net/ publication/222388936

[22] Rossi, P.; Arca, a.; Parant, e.; Fakhri, P. Bending and compressive behaviors of a new cement composite. Journal Cement and Concrete Research, v.35, n.1, 2005; p.27-33. http://www.sciencedirect.com/science/article/pii/ S0008884604002492

[23] Lim, D.H. and Nawy, E. G. Behavior of plain and steel-fiberreinforced high-strength concrete under uniaxial and biaxial compression. Journal Magazine of Concrete Research, v.57, n.10, 2005; p.603-610. http://www.icevirtuallibrary.com/doi/ pdf/10.1680/macr.2005.57.10.603

[24] Graybeal, B. Compressive behavior of Ultra-High Performance Fiber Reinforced Concrete. Journal ACI Materials, v.104, n.2, 2007; p.146-152. https://www. researchgate.net/publication/259435679

[25] Thanh, LE. Ultra high performance fiber reinforced concrete paving flags, Liverpool, 2008, PHD Thesis - University of Liverpool, 670 p. http://ethos.bl.uk/OrderDetails.do?uin=uk. bl.ethos. 502191

[26] De Larrard, F. Concrete Mixture Proportioning: A Scientific Approach, London: E \& FN Spon, 1ed, 1999, 419 p. http://d. telegchannel.com/1/10/18/2409770b-d9ab-4c65-ba02b8a3bd71ef50.pdf

[27] Toledo, R.; Koenders, E.; Formagini, S.; Fairbairn, E. Performance assessment of Ultra High Performance Fiber Reinforced Cementitious Composites in view of sustainability. Journal Materials and Design, v.36, 2012; p.880-888. http://www.sciencedirect.com/science/article/pii/ S026130 6911006364

[28] Wu, Z.; Shi, C.; Khayat, K. Influence of silica fume content on microstructure development and bond to steel fiber in ultra-high strength cement based materials (UHSC). Journal Cement and Concrete Composites, v.71, 2016; p.97-109. http://www.sciencedirect.com/science/article/pii/ S0958946516301317

[29] Lampropoulos, A; Paschalis, S.; Tsioulou, O.; Dritsos, S. Strengthening of reinforced concrete beams using ultra high performance fiber reinforced concrete (UHPFRC). Journal Engineering Structures, v.16, 2016; p.370-384. http://www. sciencedirect.com/science/article/pii/ S0141029615006768

[30] Liu, J.; Han, F.; Cui, G.; Zhang, Q.; Lv, Z.; Zhang, L.; Yang, Z. Combined effect of coarse aggregate and fiber on tensile behavior of ultra-high performance concrete. Journal Constructions and Building Materials, v.121, 2016; p.310-318. http://www.sciencedirect.com/science/article/ pii/S0950061816307620

[31] Kang, S.; Choi, J.; Koh, K.; Lee, K.; Lee, B. Hybrid effects of steel fiber and microfiber on the tensile behavior of ultrahigh performance concrete. Journal Composites Structures, v.145, 2016; p.37-42. http://www.sciencedirect.com/science/ article/pii/S0263822316301167

[32] Lee, J.; Hong, S.; Joh, Ch.; Kwahk, I.; Lee, J. Biaxial tension- 
compression strength behaviour of UHPRC in plane elements. Journal Materials and Structures, v.50, 2017; p.1-17. https:// link.springer. com/article/10.1617/s11527-016-0918-1

[33] Hoang, A and Fehling, E. Influence of steel fiber content and aspect ratio on the uniaxial tensile and compressive behavior of ultra-high performance concrete. Journal Construction and Building Materials, v.153, 2017; p.790-806. http://www. sciencedirect.com/science/article/pii/S0950061817314733

[34] Kahanji, Ch.; Ali, F.; Nadjai, A. Structural performance of ultra-high performance fiber-reinforced concrete beams. Journal Structural Concrete, v.18, 2017; p.249-258. http:// onlinelibrary.wiley.com/doi/10.1002/suco.201600006/full

[35] Wu, Z.; Shi, C.; He, W.; Wang, D. Static and dynamic compressive properties of ultra-high performance concrete (UHPC) with hybrid steel fiber reinforcements. Journal Cement and Concrete Composites, n.79, 2017; p.148-157. http://www. sciencedirect.com/science/article/pii/S0958946517301622

[36] Alsalman, A.; Dang, C.; Micah, W. Development of ultrahigh performance concrete with locally available materials. Journal Construction and Building Materials, v.133, 2017; p.135-145. http://www.sciencedirect.com/science/article/pii/ S0950061816319468

[37] Ayan, E.; Saatçioglu, Ö.; Turanli, L. Parameter optimization on compressive strength of steel fiber reinforced high strength concrete. Journal Construction and Building Materials, v.25, 2011; p.2837-2844. http://www.sciencedirect.com/science/ article/pii/S0950061810007427

[38] Uysal, Mucteba. Taguchi and Anova approach for optimization of design parameters on the compressive strength of HSC. Journal Magazine of Concrete Research, v.64, 2012; p.727-735. http://www.icevirtuallibrary.com/doi/ abs/10.1680/macr.11.00156

[39] Yoon, S.; Monteiro, P.; Macphee, D.; Glasser, F.; Salah, M. Statistical evaluation of the mechanical properties of highvolume class $\mathrm{F}$ fly ash concretes. Journal Construction and Building Materials, v.54, 2014; p.432-442. http://www. sciencedirect.com/science/article/pii/S0950061813012348

[40] Mukharjee, B. and Barai, S. Assessment of the influence of Nano-Silica on the behavior of mortar using factorial design of experiments. Journal Construction and Building Materials, v.68, 2014; p.416-425. http://www.sciencedirect. com/science/article/pii/S095006181400693X

[41] ASSOCIAÇÃO BRASILEIRA DE NORMAS TÉCNICAS. Agregados - Amostragem - NBR NM 26, Rio de Janeiro, 2001.

[42] ASSOCIAÇÃO BRASILEIRA DE NORMAS TÉCNICAS. Cimento Portland Determinação da Resistência à Compressão - NBR 7215, Rio de Janeiro, 1995.

[43] ASSOCIAÇÃO BRASILEIRA DE NORMAS TÉCNICAS. Concreto - Ensaio de compressão de corpos de prova cilíndricos - NBR 5739, Rio de Janeiro, 2007. 